\title{
PENGEMBANGAN PERANGKAT PEMBELAJARAN MATEMATIKA BERBASIS PENDIDIKAN KARAKTER KREATIF DI SEKOLAH DASAR
}

\author{
Indri Anugraheni ${ }^{凶}$
}

PGSD FKIP Universitas Kristen Satya Wacana Salatiga

\section{Info Artikel}

Sejarah Artikel:

Diterima: 21 Mar 2018

Direvisi: 28 Mar 2018

Dipublikasikan: Jun 2018

\section{Keywords:}

Mathematics Learning

Device, Creative Character

Education

\section{Abstract}

This study aims to produce learning tools in the form of Learning Implementation Plan and Student Lecture Sheet based on creative character in the fourth grade of elementary school, knowing the practicality of learning tools based on creative character developed in elementary school. This development research refers to the 4-D development model of Thiagarajan, Semmel, \& Semmel that has been adapted into three development procedures: 1) define, 2) design, and 3) develop. This study only until the development of learning tools. Then the learning device is tested the validity. Expert and practitioner validation results indicate that the Lesson Plans of 87.62 is in good category and the Student Worksheet of 81.90 is in the good category. Therefore, educational device based on creative character is suitable for use in the fourth grade of elementary school.

\begin{abstract}
Abstrak
Penelitian ini bertujuan untuk menghasilkan perangkat pembelajaran matematika yang berupa Rencana Pelaksanaan Pembelajaran dan Lembar Kerja Siswa berbasis karakter kreatif di kelas IV Sekolah Dasar, mengetahui kepraktisan perangkat pembelajaran matematika berbasis karakter kreatif di Sekolah dasar yang dikembangkan. Penelitian ini merupakan penelitian pengembangan yang mengacu pada model pengembangan 4-D dari Thiagarajan, Semmel, \& Semmel yang telah diadaptasi menjadi tiga prosedur pengembangan yaitu: 1) define, 2) design, dan 3) develop. Penelitian ini hanya sampai pengembangan perangkat pembelajaran yang menghasilkan produk dan penelitian ini tidak dilakukan implementasi secara luas. Kemudian perangkat pembelajaran di uji validitasnya. Hasil validasi ahli dan praktisi menunjukkan bahwa Rencana Pelaksanaan Pembelajaran yaitu 87,62 berada pada kategori baik dan Lembar Kerja Siswa (LKS) yaitu 81,90 berada pada kategori baik. Oleh karena itu perangkat pembelajaran matematika berbasis pendidikan karakter kreatif layak digunakan di kelas IV Sekolah Dasar
\end{abstract}

(C) 2018 Universitas Muria Kudus 


\section{PENDAHULUAN}

Pendidikan merupakan usaha sadar dan terencana dalam mewujudkan suasana belajar mengajar dan proses kegiatan pembelajaran dimana peserta didik secara aktif mampu mengembangkan semua potensi yang ada dalam dirinya untuk memiliki kekuatan spiritual keagamaan, pengendalian diri, masyarakat, bangsa dan Negara (Undang-Undang No 20 Tahun 2003). Kegiatan pembelajaran dilaksanakan di sekolah baik di tingkat pendidikan dasar hingga pendidikan tinggi. Kegiatan pembelajaran dikemas dalam mata pelajaran yang diberikan kepada siswa.

Matematika merupakan pelajaran yang diajarkan pada semua tingkatan pendidikan baik di tingkat sekolah dasar hingga pendidikan tinggi (Karim 2011: 21). Matematika merupakan bidang ilmu yang mempelajari struktur, bilangan, geometri, besaran. Matematika yang diajarkan di sekolah dasar terdiri dari 3 materi pokok yaitu bilangan, geometri dan statistika dasar. Oleh karena itu, matematika mempunyai peranan penting baik di dunia pendidikan maupun dalam kehidupan kita sehari-hari.

Keberhasilan guru dalam melaksanakan kegiatan pembelajaran diukur dari hasil belajar yang diperoleh siswa. Jika hasil belajar yang dihasilkan siswa tinggi maka guru dianggap telah berhasil melaksanakan proses kegiatan pembelajaran. Wanabuliandari (2016: 140) menyatakan konsep pembelajaran dapat dilaksanakan bila informasi tersebut menarik dan memotivasi siswa untuk terus belajar. Oleh karena itu sebelum melakukan kegiatan pembelajaran di kelas, guru harus mampu mempersiapakan, merancang pembelajaran yang menarik dan mampu menumbuhkan aktivitas siswa.

Persiapan yang dilakukan guru adalah mampu membuat perangkat pembelajaran berbasis karakter yang terdiri dari lembar Rencana Pelaksanaan Pembelajaran (RPP), Lembar Kerja Siswa (LKS), Bahan Ajar Pembelajaran, Penilaian pembelajaran. Penilaian pembelajaran terdiri dari 3 ranah yaitu ranah kognitif (pengetahuan), ranah afektif (sikap) dan ranah psikomotorik (keterampilan). Lembar Rencana Pelaksanaan Pembelajaran (RPP) merupakan rancangan atau rencana kegiatan tatap muka yang dibuat guru dalam satu atau lebih pembelajaran untuk mencapai tujuan pembelajaran. Lembar Kerja Siswa (LKS) adalah lembar yang berisi tugas-tugas yang dilakukan siswa, petunjuk melakukan kegiatan pembelajaran, langkah-langkah yang hasrus diselesaikan siswa dalam suatu kegiatan pembelajaran.

Hasil observasi yang dilakukan di SD Negeri Sidorejo Kidul 2 ditemukan beberapa permasalahan yang dihadapi guru. Permasalahan yang dihadapi guru adalah: penyusunan Rencana Pelaksanaan Pembelajaran (RPP) yang hanya mencopy RPP tahun sebelumnya tanpa ada pengembangkan RPP, RPP yang ada sudah berbasis karakter yang dikembangkan tetapi karakter yang dikembangkan masih belum maksimal, Lembar Kerja Siswa (LKS) yang belum ada.

Permasalahan yang ditemukan pada penelitian ini relevan dengan penelitian sebelumnya yaitu penelitian yang telah dilakukan oleh Akhlis dan Dewi (2014: 87) meneliti bahwa perangkat pembelajaran yang dibuat guru kurang mendukung usaha yang dilakukan guru untuk mengembangkan potensi yang ada pada diri siswa secara maksimal termasuk pembentukan karakter siswa. Listyawati (2012: 62) yang meneliti bahwa guru mengalami kesulitan dalam membuat perangkat pembelajaran dalam melakukan kegiatan mengajar. Penelitian yang dilakukan Susanto (2012: 72) menyebutkan bahwa guru dalam kegiatan pembelajaran belum menggunakan model pembelajaran yang bervariasi dan guru tidak melengkapi diri dengan perangkat pembelajaran yang ada sehingga kegiatan pembelajaran yang dihasilkan kurang sistematis. Berdasarkan beberapa penelitian tersebut dan hasil observasi di lapangan maka peneliti melakukan penelitian tentang pengembangan perangkat pembelajaran (RPP dan LKS) di kelas IV pada kurikulum 2013.

Pendidikan karakter merupakan pendidikan yang wajib diajarkan kepada siswa khususnya di tingkat dasar. Pendidikan karakter yang diberikan sejak di tingkat dasar mampu menghasilkan manusia yang berkarakter. Manusia yang berkarakter di lingkungan keluarga, di lingkungan sekolah, dan di lingkungan masyarakat. Sekolah mempunyai peranan penting dalam mendidik, menanamkan nilai-nilai moral, nilai-nilai sosial yang mampu menghasilkan manusia yang berkarakter. Hal ini sejalan dengan penelitian yang dilakukan Zuchdi dkk (2010) menjelaskan bahwa pendidikan karakter merupakan kebutuhan vital yang menjadi bekal bagi generasi penerus dengan kemampuan-kemampuan dasar yang mampu menjadikannya life-long learners yaitu sebagai salah satu karakter.

Afandi (2011: 87) menyebutkan bahwa pendidikan karakter merupakan suatu sistem 
pendidikan yang mengutamakan penanamkan nilai-nilai sesuai dengan budaya bangsa dan komponen dari aspek pengetahuan (kognitif), sikap (afektif) dan tindakan baik terdadap Tuhan Yang Maha Esa (YME), diri sendiri, masyarakat dan bangsa. Sedangkan Abidin (2012: 166) berpendapat pendidikan karakter merupakan pendidikan yang mengembangkan nilai-nilai kharakter pada diri peserta didik (siswa) sehingga mereka memiliki nilai-nilai dan karakter yang ada sebagai karakter dirinya, menerapkan nilai karakter dalam kehidupan sehari-hari sebagai anggota masyarakat, anggota warga Negara yang nasional, produktif, religius dan kreatif.

Berdasarkan pendapat tersebut maka dapat disimpukan bahwa pendidikan karakter adalah sistem pendidikan yang mampu menanamkan nilai-nilai karakter (moral, sosial, agama) kepada peserta didik (siswa) sehingga peserta didik dapat mengimplementasikan nilainilai karakter dalam kehidupan sehari-hari. Agar sistem pendidikan dapat menanamkan nilai-nilai karakter terhadap peserta didik/siswa maka perlunya penerapan nilai-nilai karakter kegiatan pembelajaran. Penerapan nilai-nilai karakter mampu menumbuhkan karakter peserta didik sehingga peserta didik dapat mengimplementasikannya dalam kehidupan sehari-hari. Karakter yang dikembangkan pada penelitian ini adalah karakter kreatif. Kreatif dalam menghasilkan karya. Hasil diskusi dengan guru, peneliti menemukan masih banyak siswa yang kreatifitasnya rendah. Daya kreatifitas siswa masih dibawah rata-rata, ideide yang dihasilkan masih melihat hasil karya orang lain, bukan hasil karya sendiri. Hal ini ditunjukan dari hasil produk yang dibuat siswa. Oleh karena itu mata pelajaran yang diberikan kepada siswa diharapkan berbasis pendidikan karakter kreatif.

Mata pelajaran yang diberikan kepada siswa terkait dengan perangkat pembelajaran yang dikembangkan oleh guru. Perangkat pembelajaran yang dikembangan guru sudah berbasis karakter, hanya belum ada penekanan pada pembelajaran berbasis karakter kreatif. Perangkat pembelajaran belum ada produk atau hasil karya siswa yang bervariasi dan inovatif. Tugas guru mampu menumbuhkan kreatifitas siswa melalui produk atau hasil karya yang inovatif dari ide-ide siswa. Perangkat pembelajaran yang dikembangkan guru berupa Rencana Pelaksanaan Pembelajaran (RPP), Lembar Kerja Siswa (LKS), Lembar penilaian soal evaluasi, media yang digunakan dalam pembelajaran. Perangkat pembelajaran yang dibuat atau dikembangkan guru diharapkan mampu menghasilkan perangkat pembelajaran yang berbasis karakter.

Pembelajaran merupakan suatu proses interaksi dalam belajar dan mengajar pada suatu kondisi yang melibatkan beberapa unsur, baik unsur intrinsik dan unsur ekstrinsik (Wahyu \& Indri 2017). Perangkat adalah alat/media yang digunakan untuk mencapai suatu tujuan atau hasil yang diharapkan. Perangkat pembelajaran dapat diartikan sebagai alat yang digunakan oleh pendidik (guru) dalam melaksanakan proses kegiatan pembelajaran sehingga tercipta interaksi antara guru dan siswa. Interaksi yang dilakuakan guru dan siswa tertuang dalam kegiatan pembelajaran. Perangkat pembelajaran yang dibuat oleh guru terdiri dari Rencana Pelaksanaan Pembelajaran (RPP), Lembar Kerja Siswa (LKS), media pembelajaran, lembar penilaian pembelajaran. Lembar Rencana Pelaksanaan Pembelajaran (RPP) disusun berdasarkan silabus yang telah dikembangkan oleh Dosen (Winarni 2013). Rencana Pelaksanaan Pembelajaran (RPP) merupakan rencana atau rancangan kegiatan pembelajaran yang dirancang oleh guru dalam satu pertemuan atau lebih. Kegiatan pembelajaran yang dirancang mampu menerapkan model-model pembelajaran yang inovatif dan berkarakter.

Penelitian dan pengembangan ini bertujuan untuk menghasilkan perangkat pembelajaran matematika berupa Rencana Pelaksanaan Pembelajaran (RPP), Lembar Kerja Siswa (LKS) berbasis Karakater Kreatif yang layak digunakan untuk pembelajaran matematika di kelas IV Sekolah Dasar. Selanjutnya, perangkat pembelajaran matematika berbasis karakter kreatif yang dikembangkan harus memenuhi tiga kriteria yaitu: layak, praktis dan efektif. Pada penelitian ini hanya mengukur kelayakan dari perangkat pembelajaran yang dikembangkan. Oleh karena itu untuk mengukur kelayakan dari perangkat pembelajaran matematika yang digunakan layak berdasarkan hasil penilaian. Untuk mengukur layak atau tidaknya perangkat pembelajaran berbasis karakter kreatif perlunya dilakukan validasi instrumen. Validasi instrumen dilakukan oleh 3 pakar pendidikan baik dari dosen UKSW, dosen Sanata Dharma dan praktisi pendidikan (guru).

\section{METODE PENELITIAN}

Model Penelitian pengembangan yang digunakan pada penelitian ini adalah 4-D dan dikembangkan oleh Thiagarajan, Semmel, \& Semmel. Model pengembangan 4-D memiliki 4 
tahap pengembangan, kemudian diadaptasi menjadi tiga tahapan, yaitu: 1) tahap Define (pendefinisian), 2) tahap Design (Perencanaan), dan 3) tahap Develop (Pengembangan).

Prosedur pengembangan yang digunakan penelitian ini adalah prosedur pengembangan menurut Thiagarajan. Sugiyono (2015: 38) menjelaskan langkah-langkah pengembangan menurut Tiagarajan:

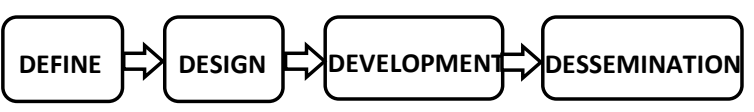

Gambar 1. Langkah-langkah penelitian dan pengembangan menurut Thiagarajan (Sugiono 2015)

Sugiono (2012: 298) menyatakan bahwa penelitian berawal dari adanya potensi atau masalah yang terjadi di lapangan. Setelah potensi atau masalah dapat ditunjukkan secara faktual atau krusial, maka selanjutnya dilakukan pengumpulan data.

Tahap Define (Pendefinisian) adalah tahap dimana peneliti mengidentifikasi permasalahan-permasalahan yang dihadapi guru. Hasil identifikasi permasalahan tersebut kemudian dianalisis dan ditemukan permasalahan-permasalahan yang dihadapi guru. Salah satu permasalahan yang dihadapi guru adalah guru mengalami kesulitan dalam membuat dan mengembangkan perangkat pembelajaran khususnya Rencana Pelaksanaan Pembelajaran (RPP) dan Lembar Kerja Siswa (LKS).

Tahap Design (Perencanaan) yaitu tahap dimana guru merencanakan dan membuat desain perangkat pembelajaran. Desain perangkat pembelajaran berupa pengembangan perangkat pembelajaran berupa Rencana Pelaksanaan pembelajaran (RPP) dan pengembangan Lembar kerja Siswa (LKS) berbasis karakter kreatif.

Tahap Develop (Pengembangan) yaitu tahap Peneliti melakukan validasi kepada pakar ahli untuk menilai apakah produk perangkat pembelajaran yang dihasilkan sudah baik atau kurang baik untuk diujikan. Peneliti melakukan validasi produk Rencana Pelaksanaan Pembelajaran (RPP) berbasis karakter yang dilakukan oleh 3 pakar bidang pendidikan yaitu pakar pembelajaran yaitu dosen dari Universitas Sanata Dharma, pakar pembelajaran yaitu dosen dari Universitas Kristen Satya Wacana (UKSW), dan Praktisi yaitu guru Sekolah Dasar Negeri Sidorejo Kidul 2.
Teknik pengumpulan data yang digunakan penelitian ini adalah data kuantitatif dan data kualitatif. Data kuantitatif diperoleh dari hasil validasi pengembangan perangkat pembelajaran berbasis karakter kreatif dan data kualitatif adalah hasil observasi permasalahan di lapangan. Untuk menguji kelayakan perangkat pembelajaran, instrumen yang digunakan dalam penelitian dan pengembangan adalah lembar penilaian kelayakan instrumen Rencana Pelaksanaan pembelajaran (RPP) berbasis karakter kreatif, lembar penilaian instrumen Lembar Kerja Siswa (LKS) berbasis kreatif pada mata pelajaran matematika di kelas 4 Sekolah Dasar.

Teknik analisis data yang digunakan dalam penelitian dan pengembangan dengan cara melakukan valiadasi instrument sesuai dengan kriteria validasi instrument pembelajaran kemudian mendeskripsikan hasil analisis datanya. Instrument validasi berupa kuesioner penilaian RPP dan LKS. Kuesioner penilaian tersebut menunjukkan hasil penskoran secara kuantitatif. Kriteria penskoran dalam kuesioner ditentukan berdasarkan tabel sebagai berikut (Kemendikbud 2014: 127)

Tabel 1. Kriteria Kualitas Perangkat Pembelajaran

\begin{tabular}{ll}
\hline Peringkat & Nilai \\
\hline Amat Baik $(\mathrm{AB})$ & $90<\mathrm{AB}<100$ \\
\hline Baik $(\mathrm{B})$ & $80<\mathrm{B}<90$ \\
\hline Cukup $(\mathrm{C})$ & $70<\mathrm{C}<80$ \\
\hline Kurang $(\mathrm{K})$ & $\leq 70$ \\
\hline
\end{tabular}

Validasi produk dilakukan oleh 3 ahli pendidikan bertujuan untuk mengetahui kelayakan dan kualitas produk sebelum di uji cobakan, rencana Pelaksanaan Pembelajaran (RPP) berbasis Karakter akan dilakukan revisi jika perolehan nilai keseluruhan dari ahli bidang pendidikan $\leq 80$.

\section{HASIL DAN PEMBAHASAN}

Hasil Validasi produk dilakukan oleh 3 ahli pendidikan bertujuan untuk mengetahui kelayakan dan kualitas produk sebelum di uji cobakan, rencana Pelaksanaan Pembelajaran (RPP) berbasis Karakter akan dilakukan revisi jika perolehan nilai keseluruhan dari ahli bidang pendidikan $\leq 80$. Berikut ini adalah rekapitulasi para ahli terhadap Rencana Pembelajaran Pelaksanaan (RPP) berbasis Karakter pada mata pelajaran matematika. Berikut adalah hasil validasi yang dilakukan oleh 3 pakar pendidikan.

Berikut adalah hasil rekapitulasi para ahli terhadap Rencana Pembelajaran Pelaksanaan 
Tabel 2. Hasil Validasi Ahli

\begin{tabular}{|c|c|c|c|c|c|c|}
\hline \multirow{2}{*}{ Aspek yang diamati } & \multirow[t]{2}{*}{ No Item } & \multicolumn{3}{|c|}{ Ahli } & \multirow{2}{*}{$\Sigma$} & \multirow{2}{*}{$\%$} \\
\hline & & A1 & $\mathrm{A} 2$ & A3 & & \\
\hline \multirow[t]{4}{*}{ Identitas Mata Pelajaran } & 1 & 4 & 4 & 4 & 12 & 80,00 \\
\hline & 2 & 4 & 3 & 3 & 10 & 66,67 \\
\hline & 3 & 5 & 4 & 4 & 13 & 86,67 \\
\hline & 4 & 5 & 4 & 4 & 13 & 86,67 \\
\hline \multirow[t]{4}{*}{ Perumusan Tujuan/Indikator } & 1 & 4 & 5 & 4 & 13 & 86,67 \\
\hline & 2 & 4 & 5 & 5 & 14 & 93,33 \\
\hline & 3 & 5 & 5 & 5 & 15 & 100,00 \\
\hline & 4 & 5 & 4 & 5 & 14 & 93,33 \\
\hline \multirow[t]{4}{*}{ Pemilihan Materi } & 1 & 4 & 4 & 5 & 13 & 86,67 \\
\hline & 2 & 4 & 5 & 4 & 13 & 86,67 \\
\hline & 3 & 4 & 4 & 4 & 12 & 80,00 \\
\hline & 4 & 5 & 5 & 4 & 14 & 93,33 \\
\hline \multirow[t]{3}{*}{ Model Pembelajaran } & 1 & 4 & 5 & 4 & 13 & 86,67 \\
\hline & 2 & 4 & 4 & 4 & 12 & 80,00 \\
\hline & 3 & 5 & 5 & 5 & 15 & 100,00 \\
\hline \multirow[t]{5}{*}{ Kegiatan Pembelajaran } & 1 & 5 & 4 & 5 & 14 & 93,33 \\
\hline & 2 & 5 & 5 & 5 & 15 & 100,00 \\
\hline & 3 & 4 & 4 & 4 & 12 & 80,00 \\
\hline & 4 & 4 & 4 & 4 & 12 & 80,00 \\
\hline & 5 & 3 & 5 & 4 & 12 & 80,00 \\
\hline \multirow[t]{3}{*}{$\begin{array}{l}\text { Pemilihan } \\
\text { Belajar }\end{array}$} & 1 & 4 & 4 & 4 & 12 & 80,00 \\
\hline & 2 & 4 & 4 & 3 & 11 & 73,33 \\
\hline & 3 & 5 & 5 & 5 & 15 & 100,00 \\
\hline \multirow[t]{2}{*}{$\begin{array}{l}\text { Pengembangan } \\
\text { Kreatif }\end{array}$} & 1 & 4 & 3 & 4 & 14 & 93,33 \\
\hline & 2 & 4 & 4 & 4 & 12 & 80,00 \\
\hline
\end{tabular}

Tabel 2 menunjukkan bahwa perangkat pembelajaran yang berupa Rencana Pelaksanaan Pembelajaran (RPP) divalidasi 3 ahli dibidang pembelajaran. Ahli pembelajaran memberikan saran/masukan terkait aspek identitas pembelajaran. Saran/masukan terkait pengembangan perangkat pembelajaran yaitu: 1) perbaikan dalam ketepatan memberikan identitas mata pelajaran yang berada pada kategori cukup, 2) perlunya perbaikan dalam membuat media pembelajaran yang sesuai dan relevan dengan daftar pustaka, 3) perlunya kesesuaian antara pengembangan karakter dalam RPP dengan model pembelajaran yang diterapkan dalam kegiatan pembelajaran di kelas.

Tabel 3. Hasil Validasi Ahli

\begin{tabular}{lcccc}
\hline \multirow{2}{*}{ Aspek yang diamati } & \multicolumn{2}{c}{ Ahli } & \multicolumn{2}{c}{ Total } \\
\cline { 2 - 5 } & $\mathrm{A} 1$ & $\mathrm{~A} 2$ & $\mathrm{~A} 3$ & $\mathbf{( \% )}$ \\
\hline Identitas Mata Pelajaran & 18 & 15 & 15 & 80,00 \\
\hline Perumusan Tujuan/Indikator & 18 & 19 & 19 & 93,33 \\
\hline Pemilihan Materi & 17 & 18 & 17 & 86,67 \\
\hline Model Pembelajaran & 13 & 14 & 18 & 88,89 \\
\hline Kegiatan Pembelajaran & 21 & 22 & 22 & 86,67 \\
\hline Pemilihan Media/Sumber Belajar & 26 & 28 & 25 & 87,78 \\
\hline Pengembangan Karakter & 8 & 7 & 8 & 76,67 \\
\hline Total Skor & 121 & 123 & 124 & \\
\hline
\end{tabular}




\begin{tabular}{llll}
\hline Nilai & 86,43 & 87,86 & 88,57 \\
\hline
\end{tabular}

Tabel 3 di atas menunjukkan hasil validasi 3 ahli yaitu ahli pembelajaran dari Universitas Sanata Dharma, ahli pembelajaran dari dalam Universitas Kristen Satya Wacana (UKSW) dan praktisi (guru SD). Hasil validasi ahli kategori "Amat Baik" diperoleh dari: persentase skor dalam merumuskan tujuan indikator dalam RPP sebesar 93,33. Hasil validasi kategori "Baik" diperoleh dari: persentase skor dalam membuat Identitas mata pelajaran sebesar 80,00; persentase skor dalam memilih materi yang sesuai dengan tujuan pembelajaran sebesar 86,67 ; persentase skor menentukan model pembelajaran yang sesuai dengan tujuan pembelajaran sebesar 88,89; persentase dalam memilih media/sumber belajar yang sesuai dengan kharakter peserta didik (siswa) sebesar 87,78. Hasil validasi kategori "cukup" diperoleh dari presentasi skor dalam mengembangkan karakter kreatif dalam pembelajaran sebesar 76,67.

Rencana Pelaksanaan Pembelajaran (RPP) berbasis karakter divalidasi oleh 3 pakar pendidikan. Hasil validasi diperoleh sebagai berikut: 1) Pakar di bidang pembelajaran (dosen Universitas Sanata Dharma) memberikan skor sebesar 86,43 ; 2) pakar di bidang pembelajaran (dosen Universitas Kristen Satya Wacana) memberikan skor sebesar 87,86; sedangkan Praktisi (guru) memperoleh skor 88,57. Rata-rata skor yang diperoleh sebesar 87,62. Berdasarkan dari kriteria penilaian perangkat pembelajaran, maka rata-rata skor 87,62 berada pada kategori "Baik". Akan tetapi peneliti tetap akan melakukan revisi berdasarkan masukan dari beberapa ahli bidang pendidikan.

Tabel 4. Hasil Validasi Ahli

\begin{tabular}{|c|c|c|c|c|c|}
\hline \multirow{2}{*}{ Aspek yang diamati } & \multicolumn{3}{|c|}{ Ahli } & \multirow{2}{*}{$\Sigma$} & \multirow{2}{*}{$\%$} \\
\hline & A1 & A2 & A3 & & \\
\hline Kesesuaian dengan SK dan KD & 4 & 5 & 4 & 13 & 86,67 \\
\hline Kesesuaian dengan kebutuhan siswa & 4 & 3 & 5 & 12 & 80,00 \\
\hline Kesesuaian dengan kebutuhan bahan ajar & 5 & 5 & 3 & 13 & 86,67 \\
\hline Kesesuaian isi materi & 3 & 5 & 5 & 13 & 86,67 \\
\hline $\begin{array}{l}\text { Kejelasan gambar, table, dan ilustrasi yang } \\
\text { digunakan }\end{array}$ & 4 & 4 & 5 & 13 & 86,67 \\
\hline $\begin{array}{l}\text { Daya Tarik dan pembangkit minat belajar } \\
\text { peserta didik }\end{array}$ & 4 & 4 & 3 & 11 & 73,33 \\
\hline Penggunaan kaidah bahasa Indonesia & 4 & 4 & 3 & 11 & 73,33 \\
\hline Jumlah & 28 & 30 & 28 & 86 & \\
\hline Skor yang diperoleh & 80,00 & 85,71 & 80,00 & & \\
\hline
\end{tabular}

Tabel 4 di atas menunjukkan hasil validasi Lembar Kerja Siswa (LKS) yang dilakukan oleh 3 ahli di bidang pembelajaran. Aspek-aspek Lembar Kerja Siswa (LKS) yang berada pada kategori "Baik" yaitu: persentase skor aspek kesesuaian dengan SK dan KD sebesar 86,67; persentase skor aspek kesesuaian dengan kebutuhan siswa sebesar 80,00 ; persentase skor aspek kesesuaian dengan kebutuhan bahan ajar sebesar 86,67; persentase skor aspek kesesuaian isi materi sebesar 86,67; persentase Kejelasan gambar, tabel, dan ilustrasi yang digunakan sebesar 86,67. Aspek Lembar Kerja siswa (LKS) berada pada kategori "cukup" yaitu persentase skor daya tarik dan pembangkit minat belajar peserta didik sebesar 73,33; dan persentase skor penggunaan kaidah bahasa Indonesia sebesar 73,33.
Hasil Validasi penilaian Lembar Kerja Siswa berbasis karakter kreatif divalidasi oleh 3 ahli/pakar di bidang pendidikan khusunya pembelajaran di Sekolah Dasar. Hasil validasi ahli/pakar disimpulkan sebagai berikut: ahli pertama di bidang pembelajaran (dosen Universitas Sanata Dharma) memberikan skor sebesar 80,00; ahli kedua di bidang pembelajaran (dosen Universitas Kristen Satya Wacana) memberikan skor sebesar 85,71; sedangkan ahli ketiga atau praktisi (Guru SD) memberikan skor sebesar 80,00. Berdasarkan kriteria penilaian perangkat pembelajaran, maka dapat disimpulkan rata-rata skor 81,90 berada pada kategori "Baik".

\section{SIMPULAN}

Berdasarkan hasil penelitian dan pengembangan perangkat pembelajaran matematika berbasis karakter kreatif di kelas IV, 
maka dapat disimpulkan sebagai berikut: 1) perangkat pembelajaran matematika berbasis karakter kreatif berupa Rencana Pelaksanaan Pembelajaran (RPP) di kelas IV layak digunakan, 2) perangkat pembelajaran matematika berbasis karakter kreatif berupa Lembar Kerja Siswa (LKS) layak untuk digunakan, 3) perangkat pembelajaran matematika yang dikembangkan telah memenuhi praktis berdasarkan hasil respon guru dan siswa.

\section{DAFTAR PUSTAKA}

Akhlis, I., \& Dewi, N. R. 2014. Pengembangan Perangkat Pembelajaran Science Berorientasi Cultural Deviance Solution Berbasis Inkuiri Menggunakan ICT untuk Mengembangkan Karakter Peserta Didik. Jurnal Pendidikan IPA Indonesia, 3(1).

Anugraheni, I. 2017. Analisa Faktor-Faktor yang Mempengaruhi Proses Belajar Guru-Guru Sekolah Dasar. Kelola: Jurnal Manajemen Pendidikan, 4(2): 205-212.

Judiani, S. 2010. Implementasi pendidikan karakter di sekolah dasar melalui penguatan pelaksanaan kurikulum. Jurnal pendidikan dan kebudayaan, 16(9): 280289.

Karim, A. 2011. Penerapan Metode Penemuan Terbimbing Dalam Pembelajaran Matematika Untuk Meningkatkan Pemahaman Konsep dan Kemampuan Berpikir Kritis Siswa Sekolah Dasar. Jurnal Pendidikan 1 (1): 21-32.

Kemendikbud. 2014. Kegemaranku: Buku GuruEdisi Revisi. Jakarta: Depdikbud.

Kemendikbud. 2014. Materi Pelatihan Implementasi Kurikulum 2013 Tahun 2014 SD Kelas I. Jakarta: Depdikbud.
Listyawati, M. 2012. Pengembangan perangkat pembelajaran IPA Terpadu di SMP. Journal of Innovative Science Education, 1(1).

Pramudita, W., \& Anugraheni, I. 2017. Studi Penguasaan Matematika Dan Bahasa Inggris Mahasiswa Program Studi Pendidikan Guru Sekolah Dasar (PGSD). Scholaria: Jurnal Pendidikan Dan Kebudayaan, 7(1): 70-82.

Sugiyono. 2016. Metode Penelitian \& Pengembangan. Alfabeta: Bandung.

Sugiyono. 2012. Metode Penelitian Kuantitatif Kualitatif dan $R$ \& D. Alfabeta: Bandung.

Susanto, J. 2012. Pengembangan Perangkat Pembelajaran Berbasis Lesson Study Dengan Kooperatif Tipe Numbered Heads Together Untuk Meningkatkan Aktivitas dan Hasil Belajar Ipa Di SD. Journal of Primary Education, 1(2).

Undang-Undang Republik Indonesia Nomor 20 tahun 2003. Tentang Sistem Pendidikan Nasional.

Wanabuliandari, S. 2016. Peningkatan Disposisi Matematis dengan Pengembangan Perangkat Pembelajaran Perangkat Matematika dengan Model Thingking Aloud Pairs Problem Solving (TAPPS) Berbasis Multimedia. Refleksi Edukatika, 6 (2): 138-144.

Winarni, S. 2013. Integrasi Pendidikan Karakter dalam Perkuliahan. Jurnal Pendidikan Karakter, 3 (1): 95-107.

Zuchdi, D. 2010. Pengembangan Model Pendidikan Karakter Terintegrasi Dalam Pembelajaran Bidang Studi Di Sekolah Dasar. Cakrawala Pendidikan, 1(3): 1-11. 